\title{
Electroencephalographic findings in asymptomatic relatives of patients with juvenile myoclonic epilepsy: relationship with the degree of kinship
}

Iris E. Martínez-Juárez, ${ }^{\text {* }}$ Aurelio Jara-Prado, ${ }^{2}$ Adriana Ochoa-Morales, ${ }^{2}$ Nancy Castro-Veloz, ${ }^{3}$

Andrea Santos-Peyret, ${ }^{1}$ Jimena Armenta-Báez ${ }^{1}$ and Mario A. Sebastián-Díaz ${ }^{4}$

${ }^{1}$ Epilepsy Clinic, Instituto Nacional de Neurología y Neurocirugía "Manuel Velasco Suárez", Mexico City; ${ }^{2}$ Neurogenetics Department, Instituto Nacional de Neurología y Neurocirugía "Manuel Velasco Suárez", Mexico City; ${ }^{3}$ Outpatient Clinic, Instituto Mexicano del Seguro Social, Durango; ${ }^{4}$ Faculty of Health Sciences, Universidad Anáhuac Norte, State of Mexico. Mexico

\begin{abstract}
Introduction: $A$ prevalence of 1 to $71 \%$ of electroencephalogram (EEG) abnormalities has been reported in asymptomatic relatives of patients with juvenile myoclonic epilepsy (JME). Objective: To determine the frequency of EEG abnormalities in asymptomatic relatives of patients with JME according to the degree of kinship. Methods: Prospective, analytical study. First-, second, and third-degree relatives of patients with JME who agreed to participate and signed informed consent were included. The analysis was descriptive, bivariate. Results: 209 asymptomatic relatives were included, out of which 115 (55\%) were females and 94 (45\%) were males, with a mean age of $35.9 \pm 16.9$ (range between 6 and 73 years). Forty-four $(21.1 \%)$ relatives had abnormal EEGs. First-degree relatives (12\%) had abnormalities more frequently in comparison with second- and third-degree relatives $(p=0.007)$. Conclusions: EEG abnormalities were observed in one third of asymptomatic relatives. It is important to highlight that there were more alterations among first-degree relatives. In the future, these findings might enable for the risk of clinically developing the disease to be estimated and for genetic counseling to be provided.
\end{abstract}

KEY WORDS: Electroencephalogram. Juvenile myoclonic epilepsy. Asymptomatic relatives.

\section{Hallazgos electroencefalográficos en familiares asintomáticos de pacientes con epilepsia mioclónica juvenil: su relación con el grado de parentesco}

\section{Resumen}

Introducción: Se ha reportado de 1 a 71 \% de prevalencia de anormalidades en el electroencefalograma (EEG) de familiares asintomáticos de pacientes con epilepsia mioclónica juvenil (EMJ). Objetivo: Determinar la frecuencia de anormalidades en el EEG en familiares asintomáticos de pacientes con EMJ de acuerdo con el grado de parentesco. Métodos: Estudio prospectivo y analítico. Se incluyeron familiares de primer, segundo y tercer grado de pacientes con EMJ, quienes aceptaron participar y firmaron el consentimiento informado. El análisis fue descriptivo bivariado. Resultados: Se incluyeron 209 familiares asintomáticos, 115 (55\%) mujeres y 94 (45\%) hombres, con edad media de $35.9 \pm 16.9$ (rango entre seis y 73 años); 44 familiares (21.1\%) tuvieron EEG anormal. Los familiares de primer grado (12\%) cursaron con mayor frecuencia con anormalidades en comparación con los de segundo y tercer grado $(p=0.007)$. Conclusiones: Se observaron anormalidades en el EEG de una tercera parte de los familiares asintomáticos. Es importante resaltar que existieron más alteraciones entre los familiares de primer grado. En un futuro, estos hallazgos permitirán estimar el riesgo de desarrollar la enfermedad clínicamente y brindar consejo genético.

PALABRAS CLAVE: Electroencefalograma. Epilepsia mioclónica juvenil. Familiares asintomáticos.

Correspondence:

*|ris E. Martínez-Juárez

E-mail: clinicadeepilepsia@innn.edu.mx
Gac Med Mex. 2021;157:411-415 Contents available at PubMed www.gacetamedicademexico.com 0016-3813/@ 2020 Academia Nacional de Medicina de México, A.C.. Published by Permanyer. This is an open access article under the CC BY-NC-ND license (http://creativecommons.org/licenses/by-nc-nd/4.0/). 


\section{Introduction}

The first description of juvenile myoclonic epilepsy (JME) was made in 1867 by Herpin, who called myocIonic jerks "secousses." Subsequently, in 1957, Janz and Christian published their article on patients with "impulsive petit mal." Delgado Escueta and Bacsal described JME as Janz's myoclonic epilepsy. ${ }^{2}$

JME is an epileptic syndrome that is responsible for 6 to $12 \%$ of all epilepsies. ${ }^{3}$ Its prevalence has been estimated to be $18 \%$ among genetic epilepsies. ${ }^{4}$ Age of presentation is between six and 22 years, but $50 \%$ of cases have an onset at between 13 and 16 years. ${ }^{5-8}$ JME starts with myoclonic seizures that usually occur after awakening and are triggered by sleep deprivation and fatigue. In addition to myoclonus, $95 \%$ of patients experience generalized tonic-clonic seizures and one third also experience absence seizures. ${ }^{9}$ Etiology is genetic, with a polygenic form of inheritance and evidence of autosomal dominant, autosomal recessive and multifactorial inheritance. ${ }^{5,10-13}$

Janz and Christian also reported that $41 \%$ of patient relatives had clinical epilepsy, most commonly mothers and daughters. There is a higher incidence of epilepsy in first-degree than in second-degree relatives in JME. ${ }^{14}$

Durón et al. ${ }^{9}$ found abnormalities on the electroencephalogram (EEG) of 24 asymptomatic relatives of patients with JME. Of the 24 relatives, $63 \%$ showed epileptiform activity characterized by $4-6 \mathrm{~Hz}$ polyspike wave complexes; $17 \%$, focal or diffuse dysfunction; $12 \%, 3-5 \mathrm{~Hz}$ spike-wave complexes; and $8 \%$, bursts of focal or diffuse sharp waves. Most asymptomatic relatives with electroencephalographic abnormalities were females.

Jayalakshmi et al..$^{14}$ evaluated 116 asymptomatic first-degree relatives of patients with JME; they found that EEG abnormalities were polyspike-wave/slow wave activity in $6 \%$ : two subjects showed a single paroxysm, while five had multiple polyspike-wave/slow wave complex paroxysms, with frequencies between 4 and $5 \mathrm{~Hz}$; only six subjects had intermittent theta activity. They also found that the incidence of epilepsy among first-degree relatives of patients with JME was $38.7 \% .^{14}$

Relatives of patients with JME may have EEG abnormalities and be asymptomatic. These findings allow genetic transmission of the disease to be understood, since relatives, particularly first-degree relatives, can be asymptomatic carriers of the mutation and only show EEG alterations.
The present study describes the frequency of electroencephalographic alterations in asymptomatic first, second, and third-degree relatives of patients with JME in a cohort of patients cared for at "Manuel Velasco Suárez" National Institute of Neurology and Neurosurgery in Mexico City. This cohort will be able to be followed over time and determine which asymptomatic relatives with EEG abnormalities will develop clinical manifestations of the disease.

\section{Methods}

An observational, prospective, cross-sectional, analytical study was carried out, which consecutively included first, second, and third-degree relatives of patients with JME cared for at the "Manuel Velasco Suárez" National Neurology Institute in January 2008 at the time of this report, who agreed to participate in the study, which has the approval of the Institute's bioethics and research committees.

Asymptomatic relatives of patients with JME cared for at the outpatient services of the epilepsy clinic were included in the study, according to the voluntary decision to participate after being informed about the possibility of doing it. Participation was not remunerated, and the participants, or their legal guardians in the case of minors, signed an informed consent or assent, respectively. Subsequently, information regarding personal data was collected and a 20-minute EEG was carried out.

Relatives older than five years were included in the study. Subjects with a history of relevant systemic or neurological disease that could modify the EEG, with a defined diagnosis of epilepsy, use of antiepileptic drugs or other drugs that modify the EEG results were excluded.

\section{Electroencephalogram recording}

EEGs were reviewed by the two epilepsy specialists who are authors of the study. Findings were classified as follows:

- Background activity: background frequency description, which in adults should be within the alpha range; in addition, reactivity, and symmetry should be described

- Intermittent light stimulation: photoparoxysmal response consisting of occipital spike, spike-wave, or polyspike-wave discharges that occur during photic stimulation 
- Brain dysfunction: diffuse or focal background rhythm slowing within the alpha range. Areas that may have some level of asymmetry, both in frequency and in generalized or focal amplitude by lobes (frontal, parietal, temporal, and occipital) should be added

- Epileptic activity: presence of graphoelements that have been described as epileptiform, such as spikes and sharp waves that are generally associated with a slow wave that follows them and that can exhibit variations such as spikesharp wave, spike-slow wave or polyspike complexes.

Electroencephalographic characteristics of discharges are well defined and include paroxysmal nature, acute morphology, negative polarity, physiological distribution field and, generally, slow wave appearance after the acute element. Only the conjunction of these elements allows epileptogenic nature to be determined. Epileptiform graphoelements can be generalized, focal, or multifocal. The different topographic distributions are correlated with the different types of epilepsy: primarily generalized or focal, generalized or focal by lobes.

Graphoelements consist of spike, polyspike, sharp wave, slow wave, spike-slow wave complex, and polyspike-slow wave complex.

\section{Statistical analysis}

For data analysis, data capture sheets were prepared and a base was generated using the SPSS program, version 15 (SPSS Inc., Chicago, USA). Descriptive analysis was carried out with means and standard deviation for numerical variables and percentages for nominal variables. Subsequently, a univariate analysis was performed, whereby first, second and third-degree relatives EEG findings were compared using the chi-square test or Fisher's exact test. For the purpose of analysis, parents were regarded as first-degree relatives; siblings and children, as second-degree relatives; and uncles/aunts, nephews and cousins, as third-degree relatives.

\section{Results}

Two hundred and nine asymptomatic relatives were included, all of whom met the inclusion criteria; $115(55 \%)$ were females and $94(45 \%)$ were males, with a mean age of $35.9 \pm 16.9$ and a range from 6 to 73 years. Regarding the distribution by degree of

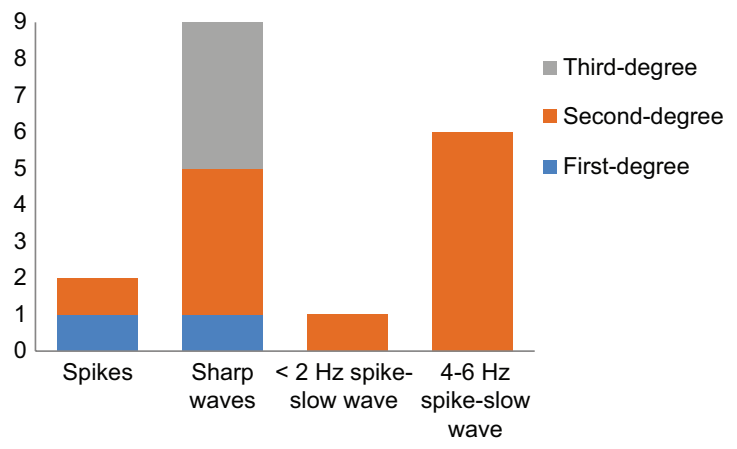

Figure 1. Type of epileptiform graphoelements in asymptomatic relatives of patients with juvenile myoclonic epilepsy according to the degree of kinship.

kinship, $89(42.6 \%)$ were found to be first-degree; $81(38.8 \%)$, second-degree; and 39 (18.7\%), third-degree relatives.

EEG was abnormal in 44 asymptomatic relatives (21.1\%). Of the evaluated relatives, none had a photoconvulsive or photoparoxysmal response. Those with the highest frequency of abnormal EEGs were second-degree relatives (Table 1).

Of the 44 relatives with abnormalities, $28(63.6 \%)$ had dysfunction, and 25 (56.8\%), epileptic activity. The most common generalized epileptic activity was the presence of 4-6 $\mathrm{Hz}$ spike-slow wave complexes. Detailed EEG findings are described in table 1 and figure 1.

Regarding the degree of kinship and the presence of EEG alterations, higher level of involvement was found in second-degree relatives ( $n=25,56.8 \%$ ), followed by first-degree $(n=10,22.7 \%)$ and third-degree relatives ( $n=9,29.5 \%)$.

In the bivariate analysis to determine the relationship between EEG abnormalities and the degree of kinship of asymptomatic relatives, a significant difference was found in the presence of an abnormal EEG in second-degree relatives $(p=0.007)$.

\section{Discussion}

This study presents the results of EEG findings in asymptomatic first, second and third-degree relatives of patients with JME. The present study is the first of this type carried out in Mexico. EEG abnormalities were found in up to one quarter $(21.1 \%)$ of asymptomatic relatives. A recent meta-analysis, which included six studies with a total of 108 patients with JME and 206 first-degree relatives, found that up to $19 \%$ had EEG abnormalities. ${ }^{15}$ 
Table 1. Abnormal electroencephalographic findings in asymptomatic relatives of patients with juvenile myoclonic epilepsy

\begin{tabular}{|c|c|c|c|c|c|c|c|c|}
\hline \multirow[t]{2}{*}{ Finding } & \multirow[t]{2}{*}{ Level of involvement } & \multicolumn{2}{|c|}{ First-degree } & \multicolumn{2}{|c|}{ Second-degree } & \multicolumn{2}{|c|}{ Third-degree } & \multirow{2}{*}{$\frac{\text { Total }}{n}$} \\
\hline & & n & $\%$ & $n$ & $\%$ & $\mathrm{n}$ & $\%$ & \\
\hline Abnormal EEG & Total & 10 & 22.7 & 25 & 56.8 & 9 & 29.5 & 44 \\
\hline Dysfunction & Total & 7 & 25 & 16 & 57 & 5 & 18 & 28 \\
\hline \multirow[t]{5}{*}{ Focal dysfunction } & Total & 7 & 29.2 & 12 & 50 & 5 & 20.8 & 24 \\
\hline & $\begin{array}{l}\text { Frontal } \\
\text { Unilateral } \\
\text { Bilateral }\end{array}$ & $\begin{array}{l}1 \\
2\end{array}$ & $\begin{array}{l}25 \\
25\end{array}$ & $\begin{array}{l}2 \\
3\end{array}$ & $\begin{array}{c}59 \\
37.5\end{array}$ & $\begin{array}{l}1 \\
3\end{array}$ & $\begin{array}{c}25 \\
37.5\end{array}$ & $\begin{array}{l}4 \\
8\end{array}$ \\
\hline & $\begin{array}{l}\text { Temporal } \\
\text { Unilateral } \\
\text { Bilateral }\end{array}$ & $\begin{array}{l}2 \\
0\end{array}$ & $\begin{array}{c}28.6 \\
0\end{array}$ & $\begin{array}{l}4 \\
0\end{array}$ & $\begin{array}{c}57.1 \\
0\end{array}$ & $\begin{array}{l}1 \\
0\end{array}$ & $\begin{array}{c}14.3 \\
0\end{array}$ & $\begin{array}{l}7 \\
0\end{array}$ \\
\hline & $\begin{array}{l}\text { Parietal } \\
\text { Unilateral } \\
\text { Bilateral }\end{array}$ & $\begin{array}{l}0 \\
0\end{array}$ & $\begin{array}{l}0 \\
0\end{array}$ & $\begin{array}{l}0 \\
2\end{array}$ & $\begin{array}{c}0 \\
100\end{array}$ & $\begin{array}{l}0 \\
0\end{array}$ & $\begin{array}{l}0 \\
0\end{array}$ & $\begin{array}{l}0 \\
2\end{array}$ \\
\hline & $\begin{array}{l}\text { Occipital } \\
\text { Unilateral } \\
\text { Bilateral }\end{array}$ & $\begin{array}{l}0 \\
2\end{array}$ & $\begin{array}{c}0 \\
100\end{array}$ & $\begin{array}{l}1 \\
0\end{array}$ & $\begin{array}{c}100 \\
0\end{array}$ & $\begin{array}{l}0 \\
0\end{array}$ & $\begin{array}{l}0 \\
0\end{array}$ & $\begin{array}{l}1 \\
2\end{array}$ \\
\hline Generalized dysfunction & & 0 & 0 & 4 & 100 & 0 & 0 & 4 \\
\hline Epileptic activity & Total & 4 & 16 & 14 & 56 & 7 & 28 & 25 \\
\hline \multirow[t]{5}{*}{ Focal epileptic activity } & Total & 3 & 17.7 & 8 & 47 & 6 & 35.3 & 17 \\
\hline & $\begin{array}{l}\text { Frontal } \\
\text { Unilateral } \\
\text { Bilateral }\end{array}$ & $\begin{array}{l}0 \\
0\end{array}$ & $\begin{array}{l}0 \\
0\end{array}$ & $\begin{array}{l}2 \\
2\end{array}$ & $\begin{array}{l}50 \\
50\end{array}$ & $\begin{array}{l}2 \\
2\end{array}$ & $\begin{array}{l}50 \\
50\end{array}$ & $\begin{array}{l}4 \\
4\end{array}$ \\
\hline & $\begin{array}{l}\text { Temporal } \\
\text { Unilateral } \\
\text { Bilateral }\end{array}$ & $\begin{array}{l}1 \\
0\end{array}$ & $\begin{array}{c}25 \\
0\end{array}$ & $\begin{array}{l}2 \\
0\end{array}$ & $\begin{array}{c}50 \\
0\end{array}$ & $\begin{array}{l}1 \\
1\end{array}$ & $\begin{array}{c}25 \\
100\end{array}$ & $\begin{array}{l}4 \\
1\end{array}$ \\
\hline & $\begin{array}{l}\text { Parietal } \\
\text { Unilateral } \\
\text { Bilateral }\end{array}$ & $\begin{array}{l}0 \\
0\end{array}$ & $\begin{array}{l}0 \\
0\end{array}$ & $\begin{array}{l}0 \\
1\end{array}$ & $\begin{array}{c}0 \\
100\end{array}$ & $\begin{array}{l}0 \\
0\end{array}$ & $\begin{array}{l}0 \\
0\end{array}$ & $\begin{array}{l}0 \\
1\end{array}$ \\
\hline & $\begin{array}{l}\text { Occipital } \\
\text { Unilateral } \\
\text { Bilateral }\end{array}$ & $\begin{array}{l}1 \\
1\end{array}$ & $\begin{array}{l}50 \\
50\end{array}$ & $\begin{array}{l}1 \\
0\end{array}$ & $\begin{array}{c}50 \\
0\end{array}$ & $\begin{array}{l}0 \\
0\end{array}$ & $\begin{array}{l}0 \\
0\end{array}$ & $\begin{array}{l}2 \\
1\end{array}$ \\
\hline Generalized epileptic activity & & 1 & 12.5 & 6 & 75 & 1 & 12.5 & 8 \\
\hline
\end{tabular}

EEG: electroencephalogram

It should be noted that the incidence of epileptiform activity on routine EEG can be up to $0.5 \%$ in healthy adults. ${ }^{16}$ In this study, up to $21.1 \%$ of asymptomatic relatives showed abnormalities, which is a higher proportion than that found in studies of healthy volunteers and in an investigation carried out in India and in the aforementioned meta-analysis. ${ }^{14,15}$ When the analysis of the association between the degree of kinship and EEG abnormal findings was carried out, significant differences were found: abnormalities were common in first-degree relatives, followed by second- and third-degree relatives. Molecular penetrance studies have recorded that the greater the kinship distance from the affected patient, the lower the risk of epilepsy. Previous analyses have described that there is a higher risk for developing generalized genetic epilepsy in members of the nuclear family. ${ }^{17,18}$

In neuropsychological tests applied to patients with JME and their siblings, abnormalities have been found in both. ${ }^{19}$ One study provided evidence that patients with JME and their asymptomatic siblings show alterations in executive function tests, such as prospective memory, with regard to healthy individuals; it was concluded that frontal dysfunctions can also be 
genetically determined in patients and healthy relatives. ${ }^{20}$ It would be interesting finding out whether this is related to the presence or absence of EEG abnormalities in relatives of patients with JME.

Study limitations include the sample size, since even when the number of analyzed subjects was adequate, abnormalities were only found in one quarter, and the results could have been more conclusive with a larger sample. Consequently, performing a risk calculation was not possible, which could have enriched the findings.

This research constitutes the basis for developing follow-up studies of individuals with EEG abnormalities, in whom JME molecular determination should be carried out and define how many of them will experience genetic epilepsy clinical manifestations at some stage of life.

\section{Conclusions}

In this study, the presence of EEG abnormalities was observed in almost one quarter of asymptomatic relatives of patients with JME. It is important to highlight that more alterations were observed in second-degree relatives.

These findings confirm JME genetic transmission, and it is therefore important to emphasize the convenience of subclinical or clinical evaluation of relatives of patients with this disease. In the future, perhaps these abnormal findings will allow to adequately estimate the risk of clinically developing the disease and thus provide genetic counseling.

\section{Acknowledgments}

The authors thank the patients and relatives who agreed to participate in this study.

\section{Conflict of interests}

The authors declare that they have no conflicts of interest.

\section{Funding}

This research did not receive any specific grants from agencies of the public, commercial, or non-profit sectors.

\section{Ethical disclosures}

Protection of human and animal subjects. The authors declare that the procedures that were followed adhered to the ethical standards of the responsible committee for experimentation on human beings and were in agreement with the World Medical Association and the Declaration of Helsinki.

Confidentiality of data. The authors declare that they followed the protocols of their work center on the publication of patient data.

Right to privacy and informed consent. The authors obtained informed consent from the patients or subjects referred to in the article. This document is in the possession of the corresponding author.

\section{References}

1. Renganathan R, Delanty N. Juvenile myoclonic epilepsy: under-appreciated and under-diagnosed. Postgrad Med J. 2003;79:78-80.

2. Delgado-Escueta A, Enrile-Bacsal F. Juvenile myoclonic epilepsy of Janz. Neurology. 1984;34:285-94.

3. Martínez-Juárez IE, Alonso ME, Medina MT, Durón RM, Bailey JN, López-Ruiz M, et al. Juvenile myoclonic epilepsy subsyndromes: family studies and long-term follow-up. Brain. 2006;129:1269-80.

4. Camfield CS, Striano P, Camfield PR. Epidemiology of juvenile myoclonic epilepsy. Epilepsy Behav. 2013;28:S15-7.

5. Alfradique I, Vasconcelos MM. Juvenile myoclonic epilepsy. Arq Neuropsiquiatr. 2007:65:1266-71.

6. Alonso ME, Medina MT, Martínez-Juárez IE, Durón RM, Bailey JN, López-Ruiz M, et al. Familial juvenile myoclonic epilepsy. Adv Neurol. 2005;95:227.

7. Kleveland G, Engelsen BA. Juvenile myoclonic epilepsy: clinical characteristics, treatment and prognosis in a Norwegian population of patients. Seizure. 1998;7:31-8.

8. Kasteleijn-Nolst-Trenite DG, Schmitz B, Janz D, Delgado-Escueta AV, Thomas P, Hirsch E, et al. Consensus on diagnosis and management of JME: from founder's observations to current trends. Epilepsy Behav. 2013;28:S87-90.

9. Durón RM, Medina MT, Martínez-Juárez IE, Bailey JN, Perez-Gosiengfiao KT, Ramos-Ramírez R, et al. Seizures of idiopathic generalized epilepsies. Epilepsia. 2005;46:34-47.

10. Bailey JN, Patterson C, de Nijs L, Durón RM, Nguyen VH, Tanaka M, et al. EFHC1 variants in juvenile myoclonic epilepsy: reanalysis according to NHGRI and ACMG guidelines for assigning disease causality. Genet Med. 2017;19:144-56.

11. Bailey JN, de Nijs L, Bai D, Suzuki T, Miyamoto H, Tanaka M, et al. Variant intestinal-cell kinase in juvenile myoclonic epilepsy. $N$ Engl $J$ Med. 2018;378:1018-28.

12. Medina M, Suzuki T, Alonso M, Durón R, Martínez-Juárez I, Bailey J, et al. Novel mutations in Myoclonin1/EFHC1 in sporadic and familial juvenile myoclonic epilepsy. Neurology. 2008;70:2137-44.

13. Suzuki T, Delgado-Escueta AV, Aguan K, Alonso ME, Shi J, Hara Y, et al. Mutations in EFHC1 cause juvenile myoclonic epilepsy. Nat Genet. 2004;36:842-9.

14. Jayalakshmi SS, Mohandas S, Sailaja S, Borgohain R. Clinical and electroencephalographic study of first-degree relatives and probands with juvenile myoclonic epilepsy. Seizure. 2006;15:177-83.

15. Tashkandi M, Baarma D, Tricco AC, Boelman C, Alkhater R, Minassian BA. EEG of asymptomatic first-degree relatives of patients with juvenile myoclonic, childhood absence and rolandic epilepsy: a systematic review and meta-analysis. Epileptic Disord. 2019;21:30-41.

16. Smith S. EEG in the diagnosis, classification, and management of patients with epilepsy. J Neurol Neurosurg Psychiatry. 2005;76:ii2-7.

17. Peljto AL, Barker-Cummings C, Vasoli VM, Leibson CL, Hauser WA, Buchhalter JR, et al. Familial risk of epilepsy: a population-based study. Brain. 2014:137:795-805.

18. Bianchi A, Viaggi S, Chiossi E, LICE Episcreen Group. Family study of epilepsy in first degree relatives: data from the Italian Episcreen Study. Seizure. 2003;12:203-210.

19. Iqbal N, Caswell HL, Hare DJ, Pilkington O, Mercer S, Duncan S. Neuropsychological profiles of patients with juvenile myoclonic epilepsy and their siblings: a preliminary controlled experimental video-EEG case series. Epilepsy Behav. 2009:14:516-21.

20. Wandschneider B, Kopp U, Kliegel M, Stephani U, Kurlemann G, Janz D, et al. Prospective memory in patients with juvenile myoclonic epilepsy and their healthy siblings. Neurology. 2010;75:2161-7. 